https://doi.org/10.18485/iipe_60nam.2021.ch28

\title{
THE NAM S\&T CENTRE - A SUCCESSFUL MECHANISM FOR CAPACITY BUILDING IN SCIENCE, TECHNOLOGY AND INNOVATION AND ACHIEVING SUSTAINABLE DEVELOPMENT GOALS IN THE GLOBAL SOUTH
}

\author{
Madhusudan BANDYOPADHYAY \\ Amitava BANDOPADHYAY ${ }^{1}$
}

\begin{abstract}
In pursuance of the decisions taken in various Conferences of the Heads of State or Government of the Non-aligned Countries, the Centre for Science and Technology of the Non-aligned and Other Developing Countries (NAM S\&T Centre) was established in New Delhi, India in 1989 as an Intergovernmental Organisation for the promotion of intensive cooperation in the fields of Science and Technology for collective selfreliance among non-aligned and other developing countries. So far, 47 NAM countries from various regions represented by their Government departments, ministries or agencies dealing with Science \& Technology have joined the Centre as its members. In order to meet its objectives, the NAM S\&T Centre has been implementing a wide range of activities on Science, Technology \& Innovation (STI), including organisation of international workshops, and training programmes/courses on various topics; award of fellowships to scientists and researchers for their affiliation with Centres of Excellence in different countries; implementation of multilateral collaborative projects; publication of books, monographs, handbooks and state-of-the-art reports; etc. The NAM S\&T Centre has been working as a facilitator in STI-driven economic development in developing countries by encouraging their governments to nurture the S\&T institutions
\end{abstract}

\footnotetext{
${ }^{1}$ Director General and Senior Adviser, Centre for Science \& Technology of the NonAligned and Other Developing Countries, New Delhi, India.

E-mail: namstcentre@gmail.com
} 
and formulating policy guidelines for the integration of science and technology into national development plans. With the successful execution of a large number of programmes in diverse areas of STI, the Centre has been able to make significant contributions in helping the developing countries in STI Policy formulation and STI Diplomacy; and capacity building of the countries of the Global South in the realisation of the Millennium and Sustainable Development Goals.

Key words: India, the Non-Aligned Movement, the NAM S\&T Centre, international cooperation, Global South, Millennium and Sustainable Development Goals

\section{Introduction}

The Non-Aligned Movement (NAM) was formed during the collapse of the colonial system and the independence struggles of the peoples of the African, Asian, Latin American and other regions of the world when the Cold War between the two Super Powers was at its peak. India's first Prime Minister Pandit Jawaharlal Nehru coined the term "Non-Aligned Movement (NAM)" during the Conference of the newly liberalized Asian and African nations held at Bandung, Indonesia during April 18-24, 1955. Twenty-nine Heads of States attended the Conference to identify and deliberate on world issues and pursue joint policies on international relations. The ten-point Bandung Principles enunciated in the Conference Declaration led to the concept of Panchsheel or the five principles that comprise: i) mutual respect for each other's territorial integrity and sovereignty; ii) mutual non-aggression; iii) mutual non-interference in each other's internal affairs; iv) equality and mutual benefit; and v) peaceful co-existence. In pursuance of the Declaration of the Bandung Conference, the Non-Aligned Movement was formally established in September 1961 at the first Summit of the Heads of State and the Government hosted by erstwhile Yugoslavia in Belgrade, through an initiative of the Indian Prime Minister Jawaharlal Nehru, Ghanaian President Kwame Nkrumah, Indonesian President Sukarno, Egyptian President Gamal Abdel Nasser and Yugoslav President Josip Broz Tito. This multilateral grouping of the South, along with the Group of 77 (G77) founded in 1964, provides a common platform for the developing countries to actively voice and articulate their views and perspectives on political and economic issues in the United Nations and other international forums, and to help them pursue their mutual interest and cooperation (South Centre, 2015). The NAM presently has 120 members representing nearly two-thirds of the United Nations' 
members and comprising 55 per cent of the world population, particularly the third world or developing countries and the emerging economies. The main purpose to form the NAM was to ensure that the newly independent countries could safeguard their independence and sovereignty, decide their own path of development and keep away from the conflicts between the two superpowers. The disintegration of the USSR in the early 1990s led to the end of the Cold War, which has brought the world to the threshold of a new era in international politics. Observers started suggesting that the NAM, which was formed as a response of the newly independent countries of the post-World War II period to domestic requirements, on the one hand, and the polarized international relations on the other, is passing through a critical period, and it is being argued that in the changed situation, nonalignment and most of the policies associated with it have become irrelevant. The $13^{\text {th }}$ NAM Summit held in Kuala Lumpur in 2003 adopted a declaration on "Continuing the Revitalization of the Non-Aligned Movement". This document along with the "Declaration on the Purposes and the Principles and the Role of the Non-Aligned Movement in the Present International Juncture" adopted at the $14^{\text {th }}$ Summit Meeting at Havana in 2006 convincingly answers the apprehensions about the Movement in the changed world scenario. These declarations highlighted the role played by the NAM on issues like decolonisation, apartheid, disarmament, poverty eradication and socioeconomic development of its members and at the same time to commit them to "the ideals, principles and purposes" of the Movement, as laid out at the Bandung Conference of 1955 and to the principles laid down in the United Nations Charter. The aims and objectives of the Non-Aligned Movement (NAM) in the current international scenario include: promotion and reinforcement of multilateral cooperation; serving as a forum of political coordination of the developing countries; promoting unity, solidarity and cooperation among the member countries to maintain international peace. The NAM also commits its members to encourage sustainable development through cooperation and respect for enjoyment and fundamental freedoms for all. The movement is committed to the principles of sustainable development and achieving the Sustainable Development Goals (SDGs), but it believes that the international community has not created conditions conducive to development and has infringed upon the right to sovereign development by each Member State. Issues such as globalisation, the debt burden, unfair trade practices, the decline in foreign aid, donor conditionality, and the lack of democracy in international financial decisionmaking are cited as factors inhibiting development (Ministry of External Affairs of India, 2012). An important element of the $17^{\text {th }}$ NAM Summit 
(September 2016, Venezuela) Declaration (now widely called the Margarita Declaration) is - "South-South Cooperation": They reiterated that South-South Cooperation is an important element of international cooperation for the sustainable development of their peoples, as a complement and not as a substitute to the NorthSouth Cooperation, which allows for the transfer of appropriate technologies, in favourable conditions and preferential terms. In this regard, they reaffirmed that South-South Cooperation is an expression of solidarity and cooperation among the peoples and countries of the South, which contributes to their national wellbeing, guided by the principles of respect for sovereignty, national ownership and independence, equality, non-conditionality, non-interference in the internal affairs, and mutual benefit (South Centre, 2016).

\section{The NAM S\&T Centre}

\section{Establishment of NAM SET Centre}

In accordance with the decisions taken in the Fifth, Sixth and Seventh Conferences of the Heads of State or Government of the Non-aligned Countries, respectively held in Colombo in 1976, Havana in 1979 and New Delhi in 1983, and in pursuance of the declaration and the "Action Programmes on the Establishment of a New International Economic Order", as well as the Charter adopted by the United Nations General Assembly and the relevant provisions of the International Development Strategy and the Caracas Programme of Action, a decision was taken at the meeting of the Plenipotentiaries of the Non-aligned countries in New York in February 1985 to set up the Centre for Science and Technology of the Non-aligned and Other Developing Countries (NAM SET Centre) as an Intergovernmental Organisation for the promotion of intensive cooperation in the fields of science and technology for collective self-reliance among non-aligned and other developing countries. In response to an offer made by the Government of India to host the Centre, the NAM S\&T Centre was established in August 1989 with its Headquarters in New Delhi. In pursuance of a decision in the Eighth NAM Summit Meeting at Harare during 1-6 September 1986, the first Intergovernmental Consultative Conference of Experts (IGCCE) on "New and High Technologies" of the non-aligned and other developing countries was held in New Delhi during 4-5 October 1988 which was attended by representatives from 25 countries. The underlying perspective emphasised the need for developing countries to collectively ensure that "High" technologies emerge through joint efforts on technology generation, adaptation, modification/alteration, and to prevent technological 
obsolescence in these countries. Most importantly, the countries of the South, together, are to take initiative and mould the high technologies as relevant to their needs and resources, and to their modernisation imperatives. Furthermore, the funding of multilateral programmes within the South must be based on the principle of collective self-reliance, with essentially no "outside" inputs. The Statute of the NAM S\&T Centre was adopted by consensus during the meeting of the Plenipotentiaries of the Non-aligned Countries in New York in February 1985 and was placed for signature by the prospective member countries. Twenty-six countries signed the Statute at that time. The Statute was again opened for signature in Pyongyang, the DPR Korea in 1987 during the NAM Foreign Ministers' meeting when five more countries signed the same. With the minimum requirement for the establishment of the Centre having been fulfilled, the Centre came into being in August 1989. In September 1989, a resolution was adopted in Belgrade at the $9^{\text {th }}$ NAM Summit urging the developing countries to join the activities of the Centre and contribute to its effectiveness as an instrument in scientific and technological cooperation of the non-aligned and other developing countries (Final Document, 1989). So far, 47 NAM countries from various regions represented by their Government departments, ministries or agencies dealing with science and technology have joined the Centre as its members. A list of current member countries of the Centre is given in Table -1 . 
Table - 1: Member Countries of NAM S\&T Centre

\begin{tabular}{|r|l|r|l|r|l|}
\hline S. No & AFRICAN & REGION & ASIAN & S. No & MIDDLE EAST \\
\hline 1. & Algeria & 18. & Afghanistan & 32. & Cyprus \\
\hline 2. & Burkina Faso & 19. & Bangladesh & 33. & Iran \\
\hline 3. & Congo & 20. & Bhutan & 34. & Iraq \\
\hline 4. & Egypt & 21. & Cambodia & 35. & Jordan \\
\hline 5. & Ethiopia & 22. & DPR Korea & 36. & Lebanon \\
\hline 6. & Gabon & 23. & India & 37. & Palestine \\
\hline 7. & Gambia & 24. & Indonesia & 38. & Malta \\
\hline 8. & Kenya & 25. & Malaysia & 39. & Syria \\
\hline 9. & Malawi & 26. & Myanmar & S. No & LaC Region \\
\hline 10. & Mauritius & 27. & Nepal & 40. & Argentina \\
\hline 11. & Nigeria & 28. & Pakistan & 41. & Bolivia \\
\hline 12. & South Africa & 29. & Sri Lanka & 42. & Colombia \\
\hline 13. & Tanzania & 30. & Vietnam & 43. & Cuba \\
\hline 14. & Togo & & & 44. & Guyana \\
\hline 15. & Uganda & S. No & EUROPE & 45. & Nicaragua \\
\hline 16. & Zambia & & & 46. & St. Lucia \\
\hline 17. & Zimbabwe & 31. & Serbia & 47. & Venezuela \\
\hline
\end{tabular}

\section{Aims, Objectives and Functions of the Centre}

Right after the setting up of the Centre in the year 1989, its functioning for the first few years was restricted mainly to the activities as required in the formative stage of any organisation - such as arranging appropriate accommodation for the Centre, providing basic infrastructure, organising manpower, raising the initial subscription from members, etc., and establishing the network of Focal Points in member countries and their institutions. The Centre drew up a programme of scientific activities, which 
was approved at the $4^{\text {th }}$ Meeting of the Governing Council in April 1993 and was taken up for implementation thereafter. Even though there were financial constraints, in order to fulfil its commitment to members, the Centre endeavoured to implement an expanded range of scientific activities over the years by generating external funding from various other sources, particularly inviting other international scientific organisations to cosponsor such programmes in areas of common interest and organising programmes on a partnership basis with national-level scientific institutions in various countries.

The main aim of the Centre is to promote various actions called for by the Action Programme for Economic Cooperation and by the Common Strategy for Cooperation in the fields of Science and Technology in order to strengthen cooperation among non-aligned and other developing countries. The objectives and functions of the Centre as stipulated in the Statute of the Centre include: to help in the establishment of links between National and Regional Centres for development and transfer of technology; promotion of fullest possible and mutually beneficial collaboration among scientists, technologists and scientific organisations from non-aligned and other developing countries; promoting the establishment of a system of meetings and consultations of scientists and technologists from non-aligned and other developing countries; to act as a clearing house of information regarding technological capabilities of the individual non-aligned and other developing countries with a view to promoting scientific and technological co-operation and transfer of technology among them, and provide early information about impending technological changes and seek to develop a data bank; maintaining a registry of S\&T experts of high calibre whose services could be utilised by the Members of the Centre; stimulating and promoting joint $R \& D$ projects and training programmes on the bilateral or multilateral basis among the members of the Centre in selected fields of special relevance; to appoint special panels of outstanding experts for the preparation of State-of-the-art Reports in respects of selected fields and problems, with a view to rendering expert advice to the members in the choice of technology, and S\&T growth, including human resources development; providing suggestions including models for balanced S\&T development based on optimum utilisation of resources; and monitoring the implementation of the programmes pertaining to S\&T development recommended at inter-governmental meetings of non-aligned and other developing countries. ${ }^{5}$ Furthermore, the Centre may perform such other functions as may be assigned to it by either a meeting of the Foreign Ministers of Non-aligned Countries or by a Summit Meeting of Heads of 
State or Government of Non-aligned Countries. Also, according to an important provision in the Statute, the Centre may, within the limits of its objectives and upon approval of the Governing Council, undertake appropriate cooperation with the United Nations and its specialised agencies as well as with other governmental and non-governmental organisations.

\section{Role of NAM S\&T Centre in the Promotion of South-South Cooperation in Science, Technology \& Innovation (STI)}

\section{Planning and Implementation of Activities}

South-South Cooperation practices are based on mutual and common interests of the developing countries and address jointly each partner's development challenges and major priorities. The partners provide and receive assistance based on their strengths and weaknesses under conditions of reciprocity and with respect to each other's sovereignty. Apart from that, South-South Cooperation seeks efficiency in the use of resources and promotes integrations between countries of the same region, as well as relations with partner countries in other regions. In this context, the NAM S\&T Centre has emerged as a unique intergovernmental entity for promoting South-South Cooperation through the application of Science, Technology and Innovation (STI) for collective self-reliance of the developing countries. Furthermore, the Centre has been attempting to include a few activities on North-South Cooperation as well for the benefit of the developing countries. The NAM S\&T Centre, soon after its establishment in August 1989, had the major task to prepare a profile of S\&T activities and programmes of mutual interest and identify policy issues that need attention to foster cooperation among the NAM and other developing countries. For this purpose, the Centre initiated interactions with member countries, and also informal get-together of the representatives of member countries were organised on South-South Cooperation in a few areas. The first informal meeting of the member countries was held on "South-South Cooperation in Science and Technology" on $13^{\text {th }}$ February 1990 in New Delhi. The second such meeting was on "South-South Cooperation in Low Cost Housing" held on 23rd August 1991 in New Delhi. The third meeting was on "South-South Cooperation in Biotechnological Applications for Food Security in Developing Countries" organised during 6-7 December 1991. During the last thirty-two years, the NAM S\&T Centre has evolved as a multifunctional international scientific institution catering to the needs of 
the developing countries for their capacity building and collective selfreliance through science and technology interventions. From its past experiences and lessons learnt thereof, the Centre has made several changes from time to time in its approach towards planning and implementation of its scientific programmes. The salient features of the present modus operandi are:

- Cooperative partnership with other organisations for sharing of organisational inputs, management and finances in holding international S\&T programmes;

- Across the board networking of scientists, experts, science managers and policymakers;

- Widespread use of electronic media in carrying out day-to-day official communications and dissemination of information to the developing countries;

- Inculcating a scientific culture within the Centre's Secretariat; and

- Encouraging young scientists, and more specifically women scientists.

Further, in order to encourage participation in the activities of the Centre and also to promote public-private partnership in Science \& Technology, a "NAM SET - Industry Network" has been set up by the Centre, which may be joined by the academic and research institutions, S\&T agencies and industry in the NAM and other developing countries as its members by paying a small annual membership fee. Currently, 16 scientific/academic institutions and industrial organisations of Bolivia, Brazil, India (10) and Nigeria (3) are the members of this Network. The above approach has led to a more visible impact of the programmes organised by the Centre. Consequently, the Center has expanded its activities in scope and content, which is reflected in the various successes it has achieved (Bandyopadhyay and Kavita, 2020).

\section{Concept of Partnership}

The Centre aims at bringing the non-aligned and other developing countries to the frontiers of science and technology through networking, sharing of knowledge, collective self-reliance, pooling of resources and mutual support. In this regard, the assistance of eminent experts is sought in preparing detailed proposals and planning of events and in the case of collaborative programmes, in the formulation of project documents. During the initial period of operation of the NAM S\&T Centre, there were not many 
institutions and scientific agencies from the member countries other than the host country India that had come forward to organise the scientific activities in partnership with the Centre. In fact, in the 1990s, most of the activities of the Centre were organised only in various Indian institutions and that too with full finances paid by the Centre. However, due to the proactive approach of the Centre and increasing popularity of the scientific contents and efficient management of its programmes, more and more institutions and agencies from other countries started coming forward to host and organise programmes in partnership with the Centre. The Centre now receives proposals from many such organisations to co-organise and host scientific events jointly with the Centre on a cost-sharing basis. In order to adopt a transparent system of partnership, the Centre has been following certain guidelines for sharing managerial responsibilities and expenditure with its prospective co-organisers/host institutions for the organisation of joint scientific events.

\section{Priority Areas for Programmes on STI}

The Intergovernmental Consultative Conference of Experts (IGCCE) on New and High Technologies of the Non-aligned and Other Developing Countries at its meeting held in October 1988 in New Delhi emphasised the need for developing countries to collectively ensure that "high" technologies emerged through joint efforts on technology generation, adaptation, modification/alteration, and to prevent technological obsolescence in these countries, and recommended that the countries of the South should take together initiative and mould the high technologies relevant to their needs and resources, and to their modernisation imperatives. The IGCCE recommended that the NAMS\&T Centre would serve as the focal point for following up of these proposals and recommendations. Keeping in view these recommendations as the guiding principles, and the immediate needs and benefit of developing countries, the Governing Council (GC) directed the Secretariat from time to time to focus on areas that should be taken up on priority while planning the activities of the Centre. The GC, in its $10^{\text {th }}$ Meeting held in Indonesia in November 2005, identified a few priority areas for the activities of the Centre, which were further modified as and when felt necessary with approvals of the GC and the Bureau of the Centre. The Centre is currently undertaking its programmes and activities in the following broad subject areas (Table -2 ) which were approved by the $15^{\text {th }}$ Governing Council Meeting held on $24^{\text {th }}$ February 2021 in Virtual Mode and hosted by Sri Lanka (NAM S\&T Centre, 2021). 
Table 2: Priority Areas of NAM S\&T Centre

\begin{tabular}{|c|c|}
\hline Sl. No. & Priority Areas \\
\hline 1. & Sustainable Agriculture; Food and Food Processing; Nutrition \\
\hline 2. & $\begin{array}{l}\text { Biotechnology including Agricultural, Medical and Industrial } \\
\text { Biotechnology; Vaccine Development Technologies }\end{array}$ \\
\hline 3. & $\begin{array}{l}\text { Drugs \& Pharmaceuticals; Traditional Systems of Medicine; } \\
\text { Herbal \& Medicinal Plants }\end{array}$ \\
\hline 4. & Materials Science \& Technology \\
\hline 5. & Minerals Processing \& Beneficiation \\
\hline 6. & Nano Science and Technology; Nano Materials \\
\hline 7. & Environment and Climate Change; Water and Air Pollution \\
\hline 8. & Sustainable Habitat and Communities \\
\hline 9. & Clean Water and Sanitation \\
\hline 10. & $\begin{array}{l}\text { Sustainable Energy including Renewable and Clean Energy; } \\
\text { Energy Conservation }\end{array}$ \\
\hline 11. & Microelectronics; Information \& Communication Technology (ICT) \\
\hline 12. & Fourth (4th) Industrial Revolution \\
\hline 13. & $\begin{array}{l}\text { Natural Disaster Mitigation \& Management; Extreme Climate Events; } \\
\text { Lightning Protection }\end{array}$ \\
\hline 14. & $\begin{array}{l}\text { STI Policy Issues including SDGs, IPR, STI Diplomacy, } \\
\text { Women Empowerment, Rural Technology, } \\
\text { S\&T Communication and Popularization }\end{array}$ \\
\hline 15. & $\begin{array}{l}\text { Innovation and Entrepreneurship; Technology Transfer } \\
\text { and Commercialization }\end{array}$ \\
\hline 16. & STEM Education and Human Resource Development \\
\hline 17. & Hydrogen Technology \\
\hline 18. & Advanced Material Technologies in Manufacturing Sectors \\
\hline 19. & Global Pandemic such as the prevailing Covid-19 \\
\hline 20. & Open Science \\
\hline 21. & $\begin{array}{l}\text { Any other areas that may be of interest } \\
\text { for the socio-economic progress of developing countries }\end{array}$ \\
\hline
\end{tabular}




\section{Activities and Programmes on STI}

In order to meet its objectives as specified in the Statute, the Centre has been implementing a wide range of scientific activities during the last thirtytwo years of its existence as listed below:

- Organisation of international workshops, roundtables, symposiums and conferences, and international training programmes/courses on various topics that are of interest to developing countries;

- Award of fellowships to scientists and researchers for their affiliation with "Centres of Excellence" in various countries;

- Implementation of multilateral collaborative projects;

- Publication of books, monographs, conference proceedings, handbooks and state-of-the-art reports;

- International partnerships and STI Diplomacy;

- Technical support for international programmes organised by other S\&T institutions and agencies;

- Dissemination of S\&T information.

Cumulative achievements in various programmes and activities of the Centre since its inception are shown in Table -3 .

Table 3: Cumulative Achievements of the Centre (up to February 2021)

\begin{tabular}{|c|l|c|}
\hline S1. No. & \multicolumn{1}{|c|}{ Programmes and Activities } & $\begin{array}{c}\text { Achievements } \\
\text { (Nos.) }\end{array}$ \\
\hline 1. & $\begin{array}{l}\text { International Workshops, Symposiums and } \\
\text { Roundtables }\end{array}$ & 82 \\
\hline 2. & International Training Programme/Course & 43 \\
\hline 3. & No. of Countries Represented & 122 \\
\hline 4. & Total No. of Participants & 6839 \\
\hline 5 & Fellowship Programmes Executed/in Operation & 12 \\
\hline 6. & Total No. of Fellowship Awardees & 386 \\
\hline 7 & Multilateral Collaborative Projects executed & 87 \\
\hline 8 & No. of Publications & 4 \\
\hline
\end{tabular}


The Organisation of International Workshops, Roundtable Meetings and Training Courses/Training Programmes

According to the Statute, the NAMS\&T Centre's objectives include, inter alia, promotion of mutually beneficial collaboration among scientists, technologists and scientific organisations from the non-aligned and other developing countries; establishment of links between national and regional centres for development and transfer of technology; and providing suggestions including models for balanced S\&T development based on optimum utilisation of resources. In order to achieve these objectives, the Centre regularly organises international workshops, conferences, roundtable meetings and training courses/training programmes in partnership with scientific agencies in various countries with appropriate sharing of organisational and fiscal responsibilities for facilitating scientistto-scientist and institution-to-institution contacts, familiarisation with and capacity building in the latest developments and techniques, and identification of collaborative projects and areas of training on research, technology and policies in different fields of science and technology. The topics of such programmes are finalised in consultation with the partner institutions and after taking approval of the Bureau/Governing Council of the Centre. Since its inception, the Centre has so far (up to February 2021) organised 125 scientific programmes including 82 international workshops, conferences and roundtable meetings; and 43 training programmes/courses on various topics, in partnership with scientific agencies in 22 host countries. A large number of scientists and professionals (almost 7,000) had participated in the international programmes organised by the Centre. Besides the member countries, scientists from a large number of nonmember developing countries, and also in some cases from the developed countries, have attended these activities either as participants or resource persons. A total of 122 countries has been represented in the workshops, conferences, roundtable meetings and training programmes organised by the Centre.

\section{Award of Fellowships for Capacity Building of Scientists and Researchers}

As another mechanism for promoting South-South and also NorthSouth Cooperation in Science and Technology, the NAM S\&T Centre has been implementing several Fellowship Schemes in different subjects in partnership with research institutions and Centres of Excellence in various countries with the aim of capacity building and upgrading the academic 
and research skills of young scientists and researchers of the developing countries. The terms and conditions including topics, duration, eligibility, sharing of expenses, etc. for each fellowship scheme are finalised in consultation with the host institution for which a Memorandum of Understanding or an Agreement of Cooperation is concluded between the two sides. Following Fellowship Programmes have been/are being implemented by the Centre:

1. Young Scientist Lectureship Award (since discontinued)

2. NAM S\&T Centre Research Fellowship (since discontinued)

3. Joint NAM S\&T Centre - ICCBS Fellowship - in partnership with International Centre for Chemical and Biological Sciences (ICCBS) of the H.E.J. Research Institute of Chemistry and Dr Panjwani Centre for Molecular Medicine and Drug Research, University of Karachi, Pakistan on Natural Products Chemistry, Herbal Medicines, Drugs, Pharmaceuticals and Neutraceuticals, Molecular Medicine, Drug Research, Clinical Research, etc.

4. Joint NAM S\&T Centre - ZMT Bremen (Germany) Fellowship - in partnership with the Centre for Tropical Marine Research (ZMT), Bremen, Germany in the fields related to Tropical Marine Systems.

5. Joint CSIR / CFTRI (Diamond Jubilee) - NAM S\&T Centre Fellowship (since discontinued) - in partnership with CSIR - Central Food Technological Research Institute (CFTRI), Mysore, India, in various fields of Food Science \& Technology for a period of six months.

6. Research Training Fellowship for Developing Country Scientists (RTFDCS) (since completed) - sponsored by the Department of Science \& Technology (DST), Govt. of India for capacity building of young researchers of the developing countries in any field of Science, Technology and Engineering by giving them opportunities to affiliate with premier academic and research institutions in India with full financial support including their international travel, and local hospitality, etc.

7. NAM S\&T Centre - DST (South Africa) Training Fellowship - for affiliation of researchers, scientists and technologists from the member countries of the NAM S\&T Centre with MINTEK, South Africa on Minerals Processing and Beneficiation.

8. NAM S\&T Centre - U2ACN2 Research Associateship (since discontinued) - in partnership with the UNESCO UNISA Africa Chair in Nanosciences \& Nanotechnology (U2ACN2), University of South Africa, Pretoria, 
9. Joint NAM S\&T Centre - ACENTDFB Fellowship - in partnership with the Africa Centre of Excellence for Neglected Tropical Diseases and Forensic Biotechnology (ACENTDFB), Nigeria, on Molecular Diagnostic and Vaccine Development for Neglected Tropical Diseases and Forensic Biotechnology.

10. NAM S\&T Centre - ASRT, Egypt Fellowship - in partnership with the Academy of Scientific Research \& Technology (ASRT), Egypt in the fields of Medical, Microbial and Plant Biotechnology.

11. Joint NAM S\&T Centre - NABDA Visiting Expert Fellowship - in partnership with the National Biotechnology Development Agency (NABDA), Nigeria on Molecular Diagnostic Research, Forensic DNA and Vaccine Development.

12. NAM S\&T Centre Senior Visiting Fellowship - to provide opportunities to senior scientists, researchers and academicians of any member country of the Centre and member of its NAMS\&T - Industry Network to affiliate themselves with the S\&T institutions located in another member country of the Centre for upgrading their research skills, undertaking short-term joint projects, delivering lectures, developing linkages and establishing closer cooperation with the scientists/ institutions in their fields of interest with full finances paid by the Centre.

So far (up to February 2021), altogether, 386 scientists and researchers have been awarded various fellowships offered by the Centre, a break-up of which is given in Table -4 . 
Table 4: Total No. of Scientists and Researchers who were Awarded Fellowships

\begin{tabular}{|c|c|c|}
\hline S1. No. & Title of Fellowship Programme & $\begin{array}{l}\text { Total No. } \\
\text { of Awardees }\end{array}$ \\
\hline 1. & $\begin{array}{l}\text { Young Scientist Lectureship Award / NAM S\&T } \\
\text { Centre Research Fellowship }\end{array}$ & 9 \\
\hline 2. & $\begin{array}{l}\text { Joint NAM S\&T Centre - ZMT Bremen (Germany) } \\
\text { Fellowship in "Tropical Coastal Marine Research" }\end{array}$ & 38 \\
\hline 3. & $\begin{array}{l}\text { Joint CSIR / CFTRI (Diamond Jubilee) - NAM S\&T } \\
\text { Centre Fellowship' on Food Science \& Technology }\end{array}$ & 9 \\
\hline 4. & $\begin{array}{l}\text { Joint NAM S\&T Centre - ICCBS Fellowship in Natural } \\
\text { Products Chemistry, Drugs and Pharmaceuticals }\end{array}$ & 32 \\
\hline 5. & $\begin{array}{l}\text { Research Training Fellowship for Developing Country } \\
\text { Scientists (RTF-DCS) }\end{array}$ & 186 \\
\hline 6. & $\begin{array}{l}\text { Joint NAM S\&T Centre - DST (South Africa) Training } \\
\text { Fellowship on Minerals Processing \& Beneficiation }\end{array}$ & 97 \\
\hline 7. & $\begin{array}{l}\text { NAM S\&T Centre - U2ACN2 (South Africa) Research } \\
\text { Associate ship in Nanosciences \& Nanotechnology }\end{array}$ & 1 \\
\hline 8. & NAM S\&T Centre Senior Visiting Fellowship & 5 \\
\hline 9. & $\begin{array}{l}\text { NAM S\&T Centre - ACENTDFB Fellowship } \\
\text { in Neglected Tropical Diseases and Forensic } \\
\text { Biotechnology }\end{array}$ & 2 \\
\hline 10. & $\begin{array}{l}\text { NAM S\&T Centre - ASRT, Egypt Fellowship } \\
\text { Programme }\end{array}$ & 5 \\
\hline \multirow[t]{2}{*}{11.} & $\begin{array}{l}\text { Joint NAM S\&T Centre - NABDA Visiting Expert } \\
\text { Fellowship Programme }\end{array}$ & 2 \\
\hline & GRAND TOTAL & 386 \\
\hline
\end{tabular}

\section{Collaborative Projects}

The Centre has the mandate to implement multilateral collaborative projects having implications on the transfer of technologies within the developing countries in various subjects that are of greater economic relevance to these countries. The Centre has successfully completed three collaborative projects partially supported by Perez-Guerrera Trust Fund 
(PGTF) of the Group of 77 (G-77) on Low-cost Housing Technology (19982003), Bio-Control of Pests and Weeds for Successful Agricultural Development (2001-2003) and Rain Water Harvesting and Groundwater Recharge - HRD and Technology Transfer (2008-2011) with the participation of a number of Member Countries. A Project on Good Asian Practices in Innovation and Development under the Regional Technical Assistance (RETA) was also implemented in 2009 with partial support of the Asian Development Bank (ADB) with the participation of eight Asian countries.

\section{Publications on Science, Technology E Innovation}

According to the Statute, the Centre has the mandate to act as a clearing house of information regarding technological capabilities of non-aligned and other developing countries with a view to promoting technological cooperation and transfer of technology among them, and provide early information about impending technological changes and seek to develop a data bank. In order to fulfil this objective, the Centre has been publishing a number of technical books, monographs, state-of-the-art reports and proceedings in various S\&T subjects. These publications are always highly rated by the scientific communities due to their excellent contents, quality and editing done by internationally renowned experts. They are also unique because while one can find a lot of information about the developed countries, the important data and status reports from the developing countries in the concerned fields of science and technology can be available only in the publications from the NAM S\&T Centre. So far (up to February 2021), the Centre has brought out 87 publications, including 74 technical books, nine workshop proceedings and four state-of-the-art reports in different areas of priority.

\section{STI Policy and Diplomacy, and International Partnerships}

Science, Technology \& Innovation (STI) is universally recognised as the key driver for economic development and poverty eradication, and an essential component for achieving the Sustainable Development Goals (SDGs). However, to make STI work for society, appropriate STI policy frameworks should be developed through consultations among the scientific community, S\&T institutions, governments and other stakeholders. In this regard, through its scientific programmes, the NAM S\&T Centre 
supports the efforts of developing countries to reorient and revise national STI systems and governance and provides technical advice, methodologies and guidance to institutions and Governments on design, monitoring and implementation of STI policies as integral parts of national development policies and plans. Further, considering that "STI Diplomacy" aids in fostering international collaborations among nations by providing an opportunity for person-to-person dialogue and exploring ways to find partnerships on bilateral, regional and global cooperation in STI, the Centre has been organising programmes to popularise the concept of STI Diplomacy and for sharing of expertise and capacity building of developing countries in this area. The above-stated activities on STI Policy and Diplomacy have been highly productive which were attended by 907 experts, professionals and policymakers from 30 countries. Further, 11 books on relevant topics were also published by the Centre comprising country status papers and scientific/research articles presented by the participants and also contributed by other experts. Most importantly, "Resolutions" were unanimously adopted during some of these events with recommendations for all stakeholders, including governments, on policy reorientation and other guidelines on STI. The Centre closely cooperates with various international organisations in connection with the implementation of its objectives and functions. In the past, the Centre established partnerships for initiating new programmes, establishing new centres of excellence and extensively disseminating the information from various agencies in the member countries - with several leading international and national level S\&T organisations across the world such as the ASEAN Committee on Science \& Technology (COST); the International Science, Technology and Innovation Centre for South-South Cooperation (ISTIC) under the aegis of UNESCO; Kenya National Commission for UNESCO (KNATCOM); the Asia-Pacific Telecommunity (APT); the Asian and Pacific Centre for Transfer of Technology (APCTT); the Centre for Space Science and Technology Education in Asia and the Pacific (CSSTEAP); G77; UN agencies like the Office for South-South Cooperation (UNOSSC), UNDP, UNEP, UNESCO and UNIDO; and Academy of Sciences for the Developing World (TWAS); Abdus Salam International Centre for Theoretical Physics (ICTP); the Asian Institute of Technology (AIT), etc. The Centre has been instrumental in planning and establishment of a few Centres of Excellence such as: the NAM African Centre for Lightning and Electromagnetics (ACLE) in Kampala, Uganda and its Zambian Centre, ACLE-Zambia; the NAM S\&T Centre of Excellence in Minerals Processing and Beneficiation (CEMPB) in Harare, Zimbabwe and the NAM Centre of 
Excellence for Dryland Agriculture in Zimbabwe. Further, the Centre has been collaborating with various other organisations to facilitate Science, Technology \& Innovation Diplomacy such as the initiatives on the Science Forum South Africa (SFSA) jointly with the Department of Science \& Innovation, South Africa; and cooperation with the Indian Ocean Rim Association (IORA) to encourage engagements in the fields of academia, science and technology for capacity building and joint activities to achieve SDGs through the application of STI in the IORA and the NAM S\&T Centre's member States for mutual benefit.

\section{Capacity Building for Achieving Sustainable Development Goals (SDGs) in the Global South - Role of the NAM S\&T Centre}

\section{Harnessing Science, Technology and Innovation to Achieve Sustainable Development Goals}

As part of a new sustainable development roadmap, the United Nations approved the 2030 Agenda, which contains the Sustainable Development Goals (SDGs). These common goals require the active involvement of individuals, businesses, administrations and countries around the world. The Sustainable Development Goals, also known as the Global Goals, are a call from the United Nations to all countries around the world to address the great challenges that humanity faces and to ensure that all people have the same opportunities to live a better life without compromising our planet. The 2030 Agenda for Sustainable Development, together with 17 Sustainable Development Goals (SDGs) and 169 specific targets, encompass the three dimensions of sustainable development: the economic, social and environmental. The agenda recognises that social and economic development depends on the sustainable management of our planet's natural resources and therefore, it is necessary to conserve and sustainably use oceans and seas, freshwater resources, as well as forests, mountains and drylands and to protect biodiversity, ecosystems and wildlife. Achieving energy and food security; improving nutrition, health and education; promoting sustainable agriculture; making cities more sustainable; and combating climate change through sustainable development find an important place among the targets of the 2030 Agenda for Sustainable Development. Science, Technology \& Innovation (STI) is an important driver for increased productivity and value addition that stimulates the growth and competitiveness of a nation. Application of STI is necessary for enabling and accelerating the global transformation towards prosperous, inclusive 
and environmentally sustainable economies in developing and developed countries alike. However, since individual non-aligned and other developing countries are at different stages of development, the targets of achieving sustainable development in each country, and thereby the mechanisms, dimensions and STI interventions need to be specific and unique for them taking into account different national realities, capacities and levels of development and keeping the national policies and priorities in focus (UN Department of Economic and Social Affairs, 2021).

\section{Role of the NAM S\&T Centre in Capacity Building of the NAM and Other Developing Countries for Achieving SDGs}

Science, Technology \& Innovation (STI) has a direct role in the implementation of almost all the 17 SDGs. In this context, it may be mentioned that with its current 47 member countries and a worldwide network of STI professionals, the NAM S\&T Centre has been vastly proactive in S\&T human capacity building; science, technology and thematic policy formulations; securing technological excellence; imparting knowledge on intellectual property rights to appropriately exploit their traditional knowledge; and creating awareness amongst developing countries about the huge impact of the STI diplomacy in getting better deals in bilateral and multilateral negotiations leading to higher trade and economic prosperity; and improving the quality of life for masses. The NAMS\&T Centre has been playing the role of a facilitator for the implementation of the Millennium Developed Goals (MDGs) that was earlier adopted for the period 2000-15, and the SDGs adopted in 2015 for the period up to 2030 - by bringing together policymakers, S\&T communities and other development professionals \& stakeholders of the developing countries. The Centre, over the years, has contributed significantly in most of the areas covered under SDGs through its various activities - international conferences, workshops, training programmes, training courses, collaborative projects, etc. Table -5 provides the quantum of scientific programmes organised by the Centre for the exchange of expertise and capacity building of the countries in the Global South for achieving various SDGs. 
Table 5: Activities of the NAM S\&T Centre on SDGs

\begin{tabular}{|c|c|c|}
\hline $\begin{array}{l}\text { SDG } \\
\text { No. }\end{array}$ & Description of Goal & \begin{tabular}{|c|} 
No. of \\
Programmes \\
Organised
\end{tabular} \\
\hline 1. & $\begin{array}{l}\text { Zero Hunger - End hunger, achieve food security and } \\
\text { improved nutrition, and promote sustainable agriculture }\end{array}$ & 10 \\
\hline 2. & $\begin{array}{l}\text { Good Health and Well-being - Ensure healthy lives } \\
\text { and promote well-being for all at all ages }\end{array}$ & 16 \\
\hline 3. & $\begin{array}{l}\text { Quality Education - Ensure inclusive and equitable } \\
\text { quality education and promote lifelong learning } \\
\text { opportunities for all }\end{array}$ & 9 \\
\hline 4. & $\begin{array}{l}\text { Gender Equality - Achieve gender equality } \\
\text { and empower all women and girls }\end{array}$ & 3 \\
\hline 5. & $\begin{array}{l}\text { Clean Water and Sanitation - Ensure availability and } \\
\text { sustainable management of water and sanitation for all }\end{array}$ & 3 \\
\hline 6. & $\begin{array}{l}\text { Affordable and Clean Energy - Ensure access to } \\
\text { affordable, reliable, sustainable and modern energy for all }\end{array}$ & 11 \\
\hline 7. & $\begin{array}{l}\text { Decent Work and Economic Growth - Promote } \\
\text { sustained, inclusive and sustainable economic growth, } \\
\text { full and productive employment and decent work for all }\end{array}$ & 5 \\
\hline 8. & $\begin{array}{l}\text { Industry, Innovation and Infrastructure } \\
\text { - Build resilient infrastructure, promote inclusive } \\
\text { and sustainable industrialization, and foster innovation. }\end{array}$ & 26 \\
\hline 9. & $\begin{array}{l}\text { Sustainable Cities and Communities } \\
\text { - Make cities and human settlements inclusive, } \\
\text { safe, resilient, and sustainable. }\end{array}$ & 9 \\
\hline 10. & $\begin{array}{l}\text { Responsible Consumption and Production - Ensure } \\
\text { sustainable consumption and production patterns. }\end{array}$ & 1 \\
\hline 11. & $\begin{array}{l}\text { Climate Action - Take urgent action to combat climate } \\
\text { change and its impacts by regulating emissions and } \\
\text { promoting developments in renewable energy }\end{array}$ & 9 \\
\hline 12. & $\begin{array}{l}\text { Life below Water - Conserve and sustainably use } \\
\text { the oceans, seas and marine resources } \\
\text { for sustainable development }\end{array}$ & 3 \\
\hline 13. & $\begin{array}{l}\text { Life on Land - Protect, restore and promote sustainable } \\
\text { use of terrestrial ecosystems, sustainably manage forests, } \\
\text { combat desertification, and halt and reverse land } \\
\text { degradation and halt biodiversity loss }\end{array}$ & 4 \\
\hline 14. & $\begin{array}{l}\text { Partnerships to Achieve the Goal - Strengthen the means } \\
\text { of implementation and revitalize the global partnership } \\
\text { for sustainable development }\end{array}$ & 13 \\
\hline
\end{tabular}




\section{Summary of Achievements and Discussion}

Since its establishment in 1989, the curve of accomplishments of the Centre has always been in the upward trend, and the Centre has succeeded in sustaining to work for achieving its mandated goal of stimulating and promoting mutually beneficial collaboration among the scientists, technologists and scientific organisations of the non-aligned and other developing countries. During this period, the Centre has proven itself to be a highly successful mechanism for the promotion of South-South Cooperation through the interventions of science, technology and innovation. With the successful execution of a large number of programmes in diverse areas of science and technology, the Centre has been striving to bring the developing countries to the frontiers of science \& technology through networking, sharing of knowledge and pooling of resources. The most significant impact of the activities of the Centre has been in the organisation of training programmes and workshops, awarding fellowships in various subjects, and publication of books and state-of-the-art reports on topics of scientific and socio-economic relevance to developing countries. The Centre has also been making efforts at establishing new connectivity for interlinking the database on S\&T experts and expertise with their national programmes and dovetailing the promotion of technological cooperation and transfer of technology initiatives with the S\&T cooperation networks in these countries. During the last three decades, the Centre has organised 125 international workshops, conferences, roundtable meetings and training courses/programmes in 20 countries with the participation of about 6,000 scientists, experts and professionals from 120 countries from all over the world. In the last decade, the Centre has laid more emphasis on the publication of books for dissemination of S\&T knowledge, and capacity building by instituting a large number of fellowship programmes. The concept of Science Diplomacy was introduced by the Centre for the first time in the developing countries by organising two workshops and publishing two books on the subject. In the recent past, the Centre has started giving special attention to a few priority subject areas for organising its programmes - such as biotechnology including industrial biotechnology; STI policy and STI Diplomacy; clean, renewable and sustainable energy; health and medicine, including herbal and traditional medicines, and natural products; innovation, entrepreneurship, technology transfer and commercialisation; information and communication technology; women's empowerment; popularisation of science - science centres and science museums; extreme climate events, and disaster mitigation and management 
and other areas. The activities of the Centre have been extremely productive in bringing together the scientific communities of the developing countries and providing a platform for the exchange of ideas, expertise and experiences and paving the way for the transfer of technologies amongst these countries. The working of the Centre has been immensely costeffective and despite its limited financial resources, an impressive range and number of programmes could be undertaken - only because of the approach of partnership with the scientific agencies in various countries. Due to the Centre's efficient management of its programmes, transparency in financial terms with its partners, and rich technical contents in the activities, several government departments, scientific agencies and academic institutions from the member countries have come forward on their own with proposals to cooperate with the Centre in hosting and jointly organising the scientific programmes of their interest.

\section{The Way Forward}

The Centre plans and evolves activities based on the requirements of the developing countries ranging from promoting high-end basic research and development of cutting edge technologies on the one hand, and to serve the technological requirements of the common man through the dissemination of appropriate skills and technologies on the other. The Centre is focused on capacity building and developing expertise in the developing countries in various important and emerging areas. However, the real achievements of the Centre are manifested in providing an opportunity for scientist-toscientist contact and interaction, familiarizing participants with the latest developments and techniques in the subject areas, identifying collaborating projects which could be taken up within the member countries, providing training and expert assistance, and identifying technologies which could be transferred among the member countries. In the wake of the recent developments and the new demands that are being placed on the STI system, it is necessary for the Centre to embark on projects of relevance to global needs and programmes on newly emerging technology areas. The efforts, therefore, would be to hold more training courses and related activities in these areas to boost South-South Cooperation in science and technology.

With the encouraging response that the Centre has received from the scientific fraternity from all over the world, the Centre has planned to expand its footprint with the following initiatives in the near future: 
While planning for the future scientific programmes and negotiating with the potential partner and host organisations, the Centre will give special attention to the emerging technologies largely facilitated by advances in digital technologies and the 4th Industrial Revolution (Industry 4.0) such as the Internet of Things (IoT), Artificial Intelligence (AI), robotics, remote sensing, big data analytics, cybersecurity, blockchain, 3-D printing, etc. - for creation of awareness and capacity building of the NAM and other developing countries in these areas.

Also, the Centre will give a further push to its activities related to the implementation of the Global Sustainable Development Agenda 2030.

Increasing attention in the publication of books, monographs and status reports for wider dissemination of S\&T knowledge among developing countries. In this connection, the Centre will take forward its plan to publish a number of scholarly as well as technology-oriented monographs in various subjects such as Lightning Protection, Ocean Science \& Technology, Dryland Agriculture, STI Diplomacy, Water and Sanitation, Biotechnology, and other subjects of importance for developing economies.

In addition to the immensely popular NAM S\&T Newsletter being published by the Centre quarterly, the Centre will also bring out a quarterly STI Bulletin which will be eventually upgraded to a peer-reviewed scientific Journal within a period of 2-3 years. An international Editorial Board will be constituted for this purpose.

New Fellowship schemes will be initiated in partnership with research institutions of various countries, including developed countries, on subjects that are not being covered at present under the currently operating fellowship schemes.

Expanding the activity on Collaborative Projects on different subjects that are of socio-economic relevance to the NAM and other developing countries with support from international financing institutions.

In pursuance of the MoU signed between the NAM S\&T Centre and the Indian Ocean Rim Association (IORA) on $7^{\text {th }}$ November 2019, the Centre will execute activities and collaborative projects in partnership with the IORA; Ministry of External Affairs, Government of India and concerned S\&T institutions in various fields such as "Cost-effective technologies for desalination of seawater/brackish water for producing potable water in coastal villages"; "Role of science, technology and innovation (STI) in achieving Sustainable Development Goals - 2030", "Technology for the cultivation of seaweeds and manufacture of value-added products", etc. 
The Centre will continue to be proactively involved in the process of establishing and working of Centres of Excellence in various areas such as Dryland Agriculture, Minerals Processing and Beneficiation, STI Diplomacy, etc.

The concept of the "NAMS\&T-Industry Network" of the Centre will be further popularized, and S\&T and academic institutions and industrial organisations in various countries will be encouraged to join the network.

A database of scientists of the developing world will be created and enlarged in priority sectors of S\&T.

\section{Conclusions}

Developing countries have several commonalities in their strengths as well as weaknesses with respect to their development and economic progress. These so-called "Countries in the South" are endowed with vast precious natural resources, flora, fauna, biodiversity, traditional knowledge and abundant cheap manpower. But at the same time, they face the problem of technological backwardness in the productive sector resulting in low production efficiency, poor quality of products and market uncompetitiveness. The natural resources possessed by them remain largely unutilised or under-utilised and are under constant threat of exploitation by the industrially developed nations. Due to a shortage of financial resources, developing countries are not in a position to make an adequate investment in science and technology. The Gross Expenditure on R\&D (GERD) by most of these countries is often much less than 1\% of GDP in stark contrast with the advanced countries, which have been consistently making a huge investment in R\&D. Their GERD usually being more than $2 \%$ of GDP, resulting in a sound infrastructure and rapid advancement in S\&T. This has led to a huge gap in scientific output and technological innovations between the North and the South. In order to bridge this knowledge divide, it has become imperative for the developing nations to work together and cooperate amongst themselves rather than perpetually depend upon the assistance from the advanced countries for harnessing the benefits of science and technology for their own development. The NAM S\&T Centre is one of the most significant intergovernmental organisations that specifically helps in promoting South-South cooperation and collective self-reliance among developing countries and facilitate their capacity building and economic growth. Since its inception, the NAM S\&T Centre has been working as a facilitator in science-driven economic development 
in the countries of the South by encouraging their governments to nurture the S\&T institutions and formulating action plans and policy guidelines for the integration of science and technology into national economic development plans. Over the years, the Centre has successfully evolved and implemented scientific activities in a wide range of subjects in order to provide an opportunity for scientist-to-scientist and institution-to-institution contacts, familiarisation with the latest developments and techniques, implementation of collaborative projects and training courses and facilitating the transfer of technology within the developing countries. The scientific activities of the Centre have helped the participating countries in capacity building and sharing of experiences and best practices in harnessing S\&T for development. The efforts of the Centre have considerably strengthened partnership between the academic and R\&D institutions within the South. The objectives of the NAM S\&T Centre, however, go well beyond the NAM, and as its name "Centre for Science and Technology of the Non-Aligned and Other Developing Countries" implies, they aim at benefiting all the developing countries through scientific and technological interventions. The essence of mutual self-reliance is that the emerging economies in the developing world provide assistance to the less endowed ones for upgrading their S\&T skills and capabilities, education and training of S\&T manpower, development and transfer of technologies for industrial applications and undertaking collaborative projects of mutual interest. Such cooperation eventually helps in minimising regional imbalance in the South and reduces the dependence on developed nations. Through South-South cooperation, efforts are made to utilise the best of science and technology from within the South itself for solving the problems facing the developing world, and the S\&T divide between the North and the South is minimised with the developing countries being able to make full use of the modern technological developments in various fields and working together to develop skills and guidelines on the protection of Intellectual Property Rights and traditional knowledge and evolve appropriate patent laws for negotiations in the WTO and other international agreements without any discrimination.

\section{References}

Bandyopadhyay, Madhusudan and Mehra, Kavita (2020). In Pursuit of Science, Technology \& Innovation: Three Decades of NAM SET Centre - A Compendium. New Delhi, Centre for Science \& Technology of the NonAligned and Other Developing Countries (NAM S\&T Centre). 
Final Document. (1989). 9th Summit Conference of Heads of State or Government of the Non-Aligned Movement, Belgrade, Serbia 4-7 September 1989, retrieved from http://cns.miis.edu/nam/documents/ Official_Document/9th_Summit_FD_Belgrade_Declaration_1989_Whol e.pdf.

Ministry of External Affairs of India. (2012). History and Evolution of NonAligned Movement, retrieved from: https://mea.gov.in/. 22.08.2012.

NAM S\&T Centre. (2021). Minutes of the 15th Meeting of the Governing Council of NAM S\&T Centre, 24 February 2021. New Delhi, Centre for Science \& Technology of the Non-Aligned and Other Developing Countries (NAM S\&T Centre).

South Centre. (2015). Revisiting the 1955 Bandung Asian-African Conference and its Legacy, South Bulletin 85, 15 May 2015.

South Centre. (2016). The NAM Summit Declaration in Summary. South Bulletin 95, 1 November 2016.

UN Department of Economic and Social Affairs. (2021). Sustainable Development Goals, retrieved from: https://sdgs.un.org/ 